\title{
Effects of Dose of Recombinant Human BMP-2 on Bone Formation at Palatal Sites in Young and Old Rats
}

\author{
Kozo YAMAJI', Masamitsu KAWANAMI², Atsushi MATSUMOTO², Tomoomi ODAJIMA², \\ Yoshihiro NISHITANI ${ }^{1}$, Kensuke IWASAKA ${ }^{3}$, Keiko YOSHIMITSU ${ }^{1}$ and Masahiro YOSHIYAMA ${ }^{1}$ \\ ${ }^{1}$ Department of Operative Dentistry, Field of Study of Biofunctional Recovery and Reconstruction, Okayama University \\ Graduate School of Medicine, Dentistry and Pharmaceutical Sciences, 2-5-1, Shikata-cho, Okayama 700-8525, Japan \\ ${ }^{2}$ Department of Periodontology and Endodontology, Division of Oral Health Science, Hokkaido University Graduate School \\ of Dental Medicine, Kita-13, Nishi-6, Kita-ku, Sapporo 060-8586, Japan \\ ${ }^{3}$ Department of Restorative and Biomaterials Sciences, Division of Operative Dentistry, Meikai University School of \\ Dentistry, 1-1, Keyakidai, Sakado 350-0283, Japan \\ Corresponding author, Kozo YAMAJI; E-mail: yamaji@md.okayama-u.ac.jp
}

Received November 27, 2006/Accepted February 16, 2007

This study was designed to examine the effects of dose of recombinant human BMP-2 (rhBMP-2) on bone formation at palatal sites in 10 -week-old $(10 \mathrm{w})$ and 70 -week-old $(70 \mathrm{w})$ rats, when combined with a polylactate-polyglycolate copolymer/gelatine sponge (PGS).

New bone formation was observed at six weeks after implantation. In the $10 \mathrm{w}$ rats, thickness of new bone (TNB) increased as the dosage increased from $0 \mu \mathrm{g}$ to $4 \mu \mathrm{g}$, and decreased significantly as the dosage increased from $8 \mu \mathrm{g}$ to $24 \mu \mathrm{g}$. In contrast, in the $70 \mathrm{w}$ rats, TNB increased as the dosage increased from $0 \mu \mathrm{g}$ to $16 \mu \mathrm{g}$, and did not significantly change as the dosage increased from $16 \mu \mathrm{g}$ to $24 \mu \mathrm{g}$.

These results suggest that the most effective dosage of rhBMP-2 for induction of bone formation varies according to age.

Keywords: Dose of rhBMP-2, Bone formation, Aging

\section{INTRODUCTION}

It has been demonstrated that recombinant human BMP-2 (rhBMP-2) could induce bone formation and enhance periodontal regeneration ${ }^{1-12}$. Use of rhBMP-2 in vivo needs a carrier material. On this account, polylactate-polyglycolate copolymer/gelatine sponge (PGS) - an improved sponge-type carrier material has been reported to be an effective carrier of rhBMP-2, $2^{2,4,67}$.

To evaluate the effects of rhBMP-2 on bone formation, it is necessary to use old animals as well as young animals. This is because the age profile of most people suffering from periodontitis or alveolar bone loss reflects the aged and elderly. We examined the effects of aging on bone formation induced by rhBMP-2 at palatal subperiosteal sites using 10-, 30-, and 70-week-old rats and found that the volume of new bone declined with aging.

In the abovementioned studies, ${ }^{4,5}$, it was not investigated at which concentration did rhBMP-2 induce maximal bone formation at a particular age. Against this backdrop, we investigated the effects dose of rhBMP-2 on bone formation using 30-weekold rats as adult age $\mathrm{e}^{6)}$. Nonetheless, it is still necessary to extend the investigation to rats of other age groups, to the end of unraveling the corresponding concentrations of rhBMP-2 which would induce maximal bone formation.

The purpose of the present study, therefore, was to examine the effects of dose of rhBMP-2 on bone formation at palatal subperiosteal sites in young and old rats.

\section{MATERIALS AND METHODS}

\section{Animals}

Forty-one 10-week-old (10w) and 42 70-week-old (70w) male Wister rats were used in this experiment. All procedures involving rats were performed in compliance with the guidelines for the care and use of laboratory animals of the School of Dentistry and Graduate School of Dental Medicine, Hokkaido University.

\section{Combination of rhBMP-2 with carrier material}

RhBMP-2 and PGS were donated by Astellas Pharmaceutical Co. Ltd. (Tokyo, Japan). RhBMP-2 was dissolved in LF6 buffer $(5 \mathrm{mM}$ sodium glutamate, $2.5 \%$ glycine, $0.5 \%$ sucrose, and $0.01 \%$ Tween $80 ; \quad \mathrm{pH}$ 4.5). PGS, composed of polylactatepolyglycolate copolymer (molar ratio at 50:50; molecular weight at 30,000 ) and gelatine sponge, was used as the absorbable carrier (Fig. 1). Weight ratio of polylactate-polyglycolate copolymer to gelatin sponge was 4:1, and porosity was approximately $90 \%$. PGS was cut into pieces of $4.0 \times 0.5 \times 1.0 \mathrm{~mm}$ (mean weight: $250 \mu \mathrm{g})$, rhBMP-2 (0.0, 4.0, 8.0, 16.0, or $24.0 \mu \mathrm{g}$ ) was added to PGS, and then the resultant product lyophilized. 


\section{Implantation}

Both $10 \mathrm{w}$ and $70 \mathrm{w}$ rats were divided into five groups according to the dosage of rhBMP-2 contained in the PGS and which was implanted: $0 \mu \mathrm{g}, 4 \mu \mathrm{g}, 8 \mu \mathrm{g}, 16$ $\mu \mathrm{g}$, and $24 \mu \mathrm{g}$.

Surgical procedures following the method of Matsumoto et $a$. $^{5}$ ) were performed under intraperitoneal anesthesia with pentobarbital sodium (40 $\mu \mathrm{g} / \mathrm{g}$ body weight) and local infiltration anesthesia with $2 \%$ lidocaine hydrochloride containing 1 : 80,000 epinephrine. After full-thickness flap was raised, implantation was done at palatal subperiosteal sites (Fig. 2).

Nylon fibers, obtained by unraveling nylon surgical sutures, were placed on the palatal bone surface as markers to distinguish new bone from original bone. PGS was implanted over the nylon fibers. The incision was then sutured (Fig. 3). At six weeks after implantation, the animals were euthanized by overdose inhalation of ether.

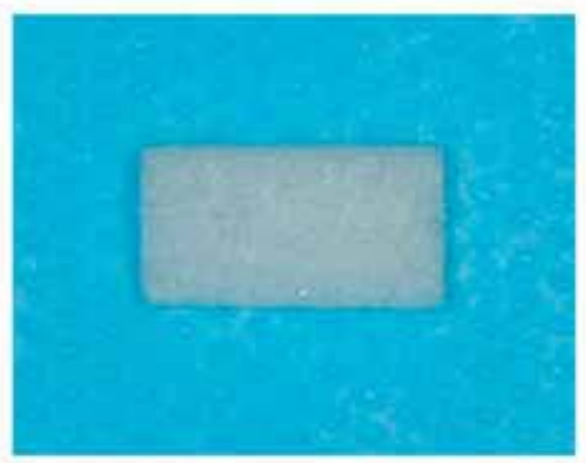

Fig. 1 Polylactate-polyglycolate copolymer/gelatine sponge (PGS) on a sterilized sheet.

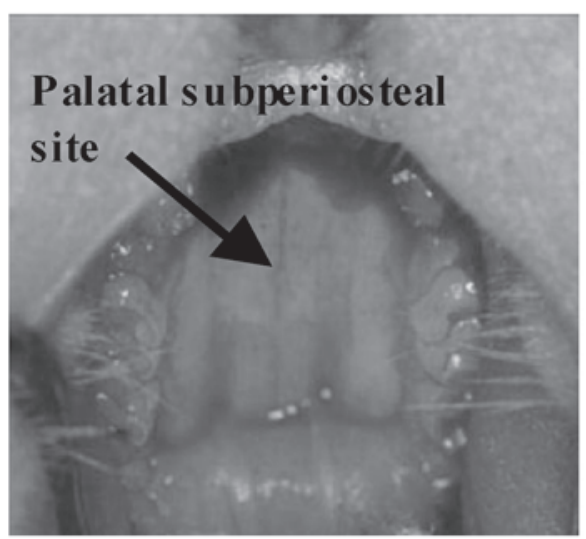

Fig. 2 Palatal subperiosteal site with full-thickness flap raised.
Histological procedures and histometric evaluations Tissue blocks including palate and molar teeth were removed, and fixed with $10 \%$ buffered formalin. Fixed tissue blocks were demineralized using PlankRychlo solution, and then embedded in paraffin. Serial sections of $5 \mu \mathrm{m}$ thickness were cut in the frontal plane throughout the entire mesiodistal extension, and stained with hematoxylin and eosin (H\&E).

Distance between the new bone surface and the most nasal position of nylon fibers was measured as the thickness of new bone using a grid (Fig. 4). Thickness of new bone (TNB) was determined by averaging the thickness of new bone of five sections at intervals of $100 \mu \mathrm{m}$ in every specimen.

\section{Statistical analysis}

The Tukey-Kramer test was used for TNB comparisons for the same group of $10 \mathrm{w}$ rats and $70 \mathrm{w}$ rats. The Mann-Whitney rank sum test was used for TNB comparisons between groups.

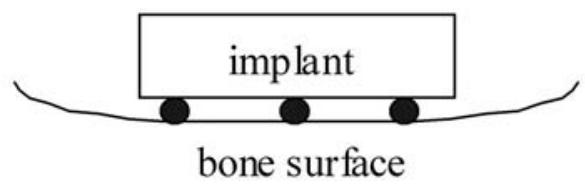

\section{: nylon fiber}

Fig. 3 Implant on the bone surface (cross section). Nylon fibers, as markers to distinguish new bone from original bone, were placed on the bone surface after a full-thickness flap was raised. Then, the implant was implanted over the nylon fibers.

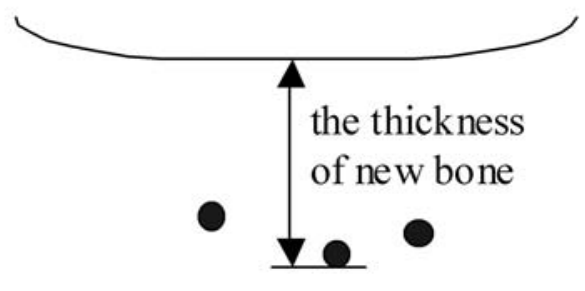

: nylon fiber

Fig. 4 Measurement of the thickness of new bone. Distance between the new bone surface and the most nasal position of nylon fiber was measured as the thickness of new bone. 


\section{RESULTS}

\section{Histological observation}

In every specimen, neither infected region nor atypical cell proliferation was observed. Implants had disappeared, leaving only the nylon fibers. New bone formation continued at the site of original bone (Figs. 5 and 6).

\section{Histometric analysis}

Table 1 shows the TNB of every group. In the $10 \mathrm{w}$ rats, TNB increased as the dosage increased from $0 \mu \mathrm{g}$ to $4 \mu \mathrm{g}$, reached the maximal level at $4 \mu \mathrm{g}$, and decreased significantly as the dosage increased from $8 \mu \mathrm{g}$ to $24 \mu \mathrm{g}$. In contrast, in the $70 \mathrm{w}$ rats, TNB increased as the dosage increased from $0 \mu \mathrm{g}$ to $16 \mu \mathrm{g}$, reached the maximal level at $16 \mu \mathrm{g}$, and did not significantly change as the dosage increased from $16 \mu \mathrm{g}$ to $24 \mu \mathrm{g}$.

There were significant differences in TNB between $10 \mathrm{w}$ and $70 \mathrm{w}$ rats at dosages of $0 \mu \mathrm{g}, 4 \mu \mathrm{g}$, and $8 \mu \mathrm{g}$. However, there were no significant differences at dosages of $16 \mu \mathrm{g}$ and $24 \mu \mathrm{g}$. The maximal TNB of $10 \mathrm{w}$ rats $(203 \pm 91 \mu \mathrm{m}$ at $4 \mu \mathrm{g})$ was significantly greater than that of $70 \mathrm{w}$ rats $(128 \pm 45 \mu \mathrm{m}$ at $16 \mu \mathrm{g})$.
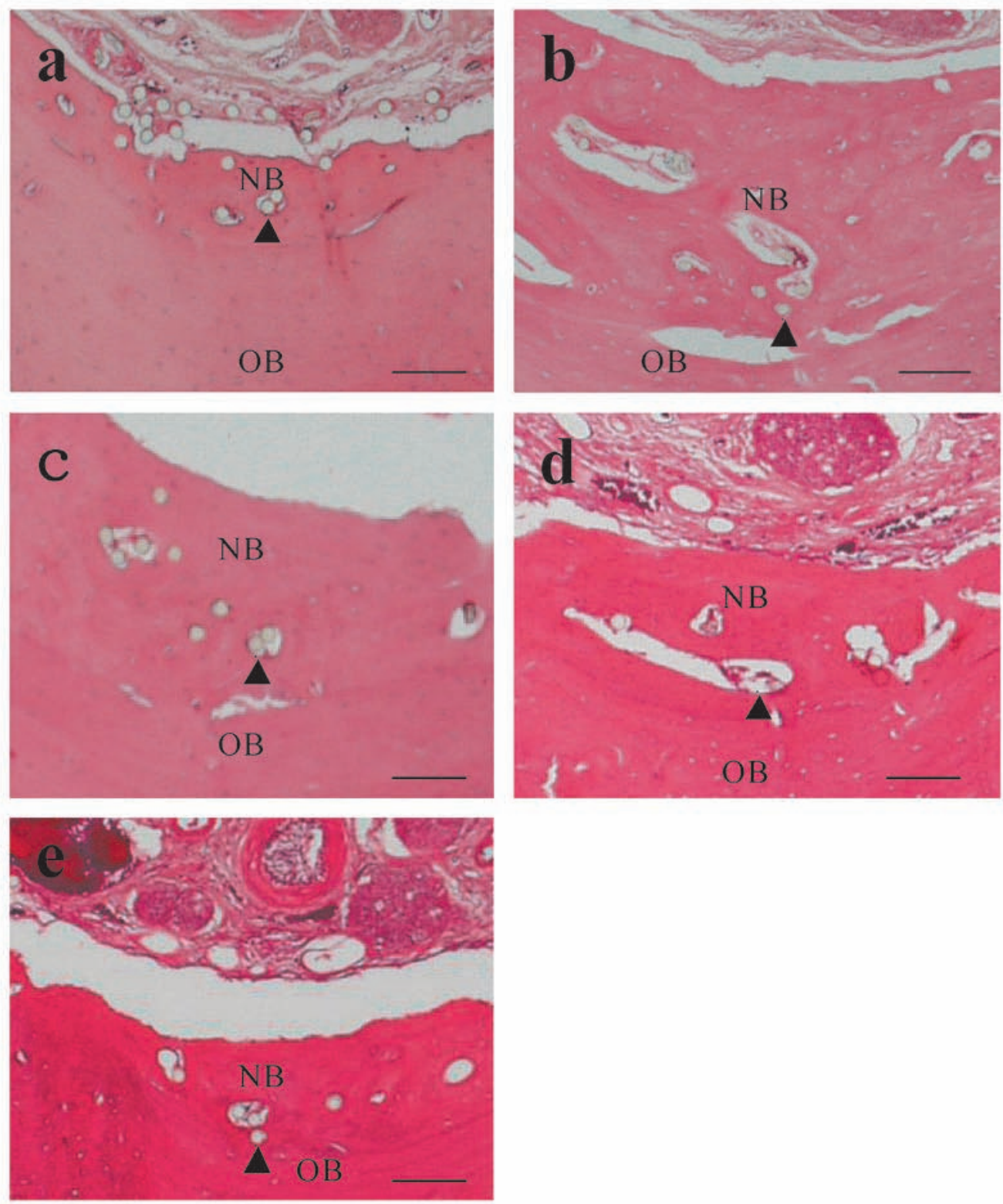

Fig. 5 Photomicrographs of group : (a) $0 \mu$ g; (b) $4 \mu$ g; (c) $8 \mu$ g; (d) $16 \mu$ g; and (e) $24 \mu$ g of $10 \mathrm{w}$ rats (H\&E staining).

Growth of new bone (NB) continued at the site of original bone (OB). Nylon fibers (arrow head) were surrounded by bone tissue $(\mathrm{bar}=100 \mu \mathrm{m})$. 

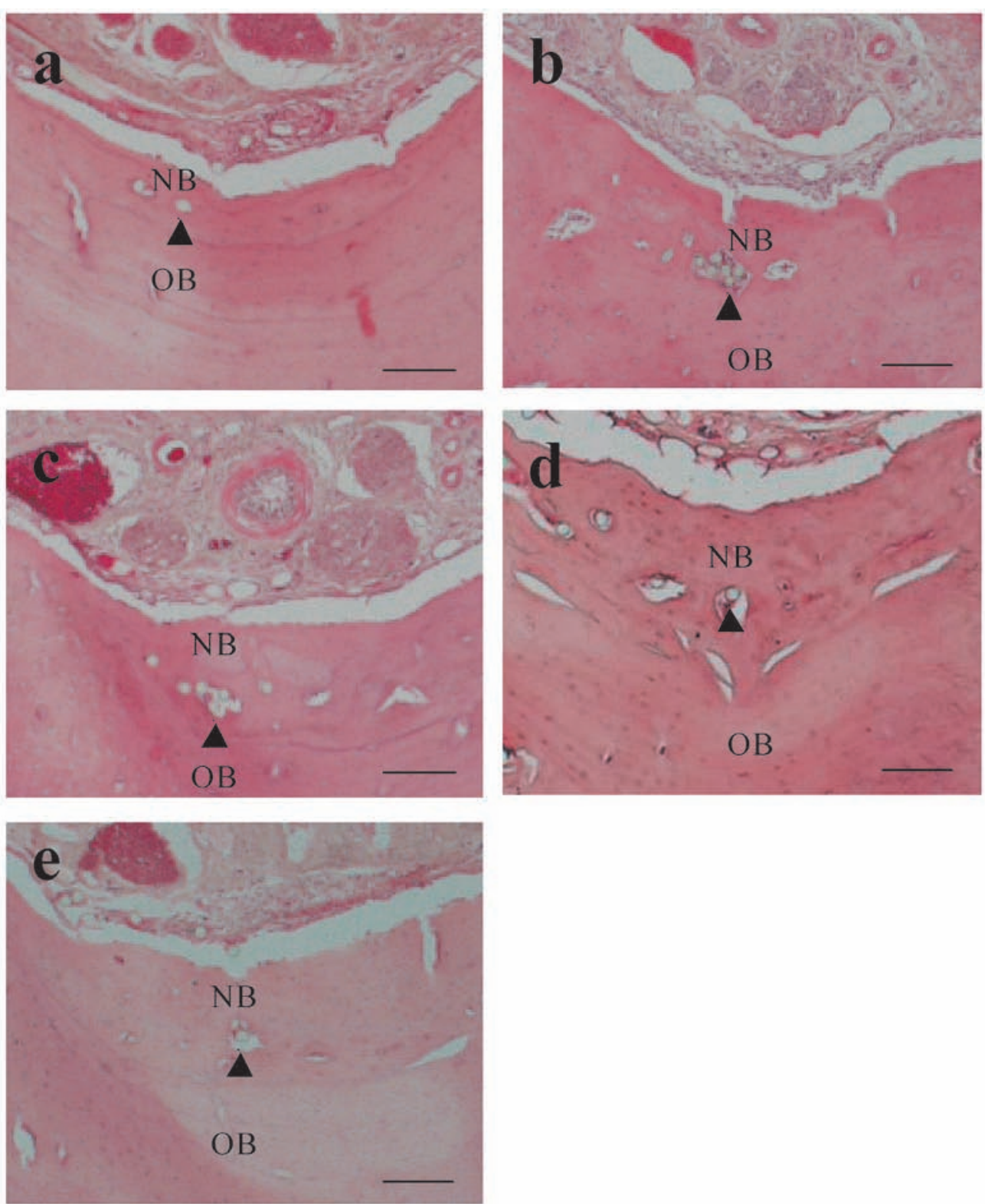

Fig. 6 Photomicrographs of group : (a) $0 \mu \mathrm{g}$; (b) $4 \mu \mathrm{g}$; (c) $8 \mu \mathrm{g}$; (d) $16 \mu \mathrm{g}$; and (e) $24 \mu \mathrm{g}$ of 70w rats (H\&E staining).

Growth of new bone (NB) continued at the site of original bone (OB). Nylon fibers (arrow head) were surrounded by bone tissue (bar $=100 \mu \mathrm{m})$.

\section{DISCUSSION}

The objective of the present study was to examine the effects of dose of rhBMP-2 on bone formation at palatal sites in 10- and 70-week-old male Wister rats.

Wister rats become reproductive adults at 9-14 weeks of age, and remain so until approximately 60 weeks of age. Their average life span is about two and a half years. Considering this background, we selected 10- and 70-week-old rats to represent young and old rats, respectively.

To apply BMP to bone augmentation or periodontal therapy, it is necessary to perform the investi- gation at submucosal sites adjacent to the jawbone, alveolar or palatal bone. This is because there is a fair possibility that implants might drop out in the case of subgingival implantation. The chief cause lies in the difficulty to suture sulcular incisions, as interproximal spaces in rats are very small. Thus we decided to use palatal subperiosteal sites in this study.

It is important to select the appropriate carrier material for BMP. It has been demonstrated that PGS was effective as a carrier of BMP, and that BMP combined with PGS could enhance periodontal regeneration ${ }^{2-7)}$. Therefore, we selected PGS as the 
Table 1 Thickness of new bone (TNB) of every group

\begin{tabular}{|c|c|c|c|c|c|}
\hline & \multicolumn{5}{|c|}{ Group } \\
\hline & $0 \mu \mathrm{g}$ & $4 \mu \mathrm{g}$ & $8 \mu \mathrm{g}$ & $16 \mu \mathrm{g}$ & $24 \mu \mathrm{g}$ \\
\hline \multicolumn{6}{|l|}{$10 \mathrm{w}$ rats } \\
\hline $\mathrm{TNB}(\boldsymbol{\mu} \mathrm{m})$ & $87 \pm 53^{a}$ & $203 \pm 91^{b}$ & $189 \pm 80^{b}$ & $135 \pm 63^{\mathrm{c} *}$ & $113 \pm 67^{\mathrm{a}, \mathrm{c}, *}$ \\
\hline Number of sites & 8 & 9 & 8 & 8 & 8 \\
\hline \multicolumn{6}{|l|}{$70 \mathrm{w}$ rats } \\
\hline $\mathrm{TNB}(\boldsymbol{\mu} \mathrm{m})$ & $18 \pm 17^{\mathrm{d}}$ & $69 \pm 35^{\mathrm{e}}$ & $101 \pm 39^{\mathrm{e}, \mathrm{f}}$ & $128 \pm 45^{\mathrm{f}, *}$ & $111 \pm 46^{\mathrm{f}, *}$ \\
\hline Number of sites & 9 & 9 & 8 & 8 & 8 \\
\hline
\end{tabular}

Same alphabets indicate no significant differences according to Tukey-Kramer test $(\mathrm{P}>0.05)$.

Same symbol $\left({ }^{*}\right)$ indicates no significant differences between the $10 \mathrm{w}$ and $70 \mathrm{w}$ rats of the same group according to Mann-Whitney rank sum test $(\mathrm{P}>0.05)$.

carrier of rhBMP-2 in this study.

It has been reported that at palatal subperiosteal sites, the implantation of rhBMP-2 combined with PGS resulted in new bone formation continuing at the site of original bone $e^{4.77}$. However, it is necessary to distinguish the new bone from the original bone histometrically.

The nylon fibers used in this study appeared to be effective markers for the histometric evaluation of new bone formation continuing at the site of original bone in decalcified specimens. This was chiefly because they seemed to have neither stimulative nor inhibitory effect on bone formation.

For histometric evaluation of new bone, an adequate postoperative observation period is necessary. In the case of short-term observations, the total amount of new bone might not be estimated because further bone formation could occur until the implanted material disappears completely. It has been demonstrated that the implantation of rhBMP-2 combined with PGS disappeared at six weeks after implantation at palatal subperiosteal sites in $\operatorname{rats}^{4,6,7}$.

Iwasaka et al. reported the implants disappeared at six weeks after implantation even in the case of rats with diabetes mellitus ${ }^{7}$. In this study, six weeks seemed to be adequate because of the evident disappearance of the implants.

In the $10 \mathrm{w}$ rats, TNB significantly increased as the dosage increased from $0 \mu \mathrm{g}$ to $4 \mu \mathrm{g}$, and significantly decreased as the dosage increased from $8 \mu \mathrm{g}$ to $24 \mu \mathrm{g}$. In contrast, in the $70 \mathrm{w}$ rats, TNB increased as the dosage increased from $0 \mu \mathrm{g}$ to $16 \mu \mathrm{g}$, and did not significantly change as the dosage increased from $16 \mu \mathrm{g}$ to $24 \mu \mathrm{g}$. These results indicated that in both $10 \mathrm{w}$ and $70 \mathrm{w}$ rats, the implantation of rhBMP-2 combined with PGS was capable of enhancing bone formation. However, the most effective dosage of rhBMP-2 differed between the $10 \mathrm{w}$ and $70 \mathrm{w}$ rats.

Maximal TNB of the $10 \mathrm{w}$ rats was significantly greater than that of the $70 \mathrm{w}$ rats. This suggested that the $70 \mathrm{w}$ rats required a greater dosage of
rhBMP-2 than the $10 \mathrm{w}$ rats, and that responsiveness to rhBMP-2 or the number of BMP-producing cells decreased with aging. These results were consistent with those of previous studies - which showed that the number and function of osteoblast cells decreased with ag in ${ }^{13,14)}$.

It has been reported that BMP caused a dosedependent increase in bone resorption in vitro ${ }^{15-22}$. Kanatani et al. examined the effects of BMP-2 on osteoclastic activity in a mouse bone cell culture ${ }^{15}$. They found that BMP-2 caused increase in bone resorption and stimulated mature osteoclast function. Putting these in vitro studies ${ }^{15-22}$ and our results together, it could be said that an effective dose of rhBMP-2 would enhance bone formation, whereas an overdose of rhBMP-2 would lead to inhibitory effect on bone formation.

In conclusion, the present results indicate that at palatal subperiosteal sites, the most effective dosage of rhBMP-2 for induction of bone formation varies according to age.

\section{ACKNOWLEDGEMENTS}

The authors hereby thank Astellas Pharmaceutical Co. Ltd. (Tokyo, Japan) for providing rhBMP-2 and the carrier material.

\section{REFERENCES}

1) Fleet JC, Cashman K, Cox K, Rosen V. The effects of aging on the bone inductive activity of recombinant human bone morphogenetic protein-2. Endocrinology 1996; 137: 4605-4610.

2) Kinoshita A, Oda S, Takahashi K, Yokota S, Ishikawa I. Periodontal regeneration by application of recombinant human bone morphogenetic protein-2 to horizontal circumferential defects created by experimental periodontitis in beagle dogs. J Periodontol 1997; 68: 103-109.

3) Wikesjö UME, Guglielmoni P, Promsudthi A, Cho KS, Trombelli L, Selvig KA, Jin L, Wozney JM. Periodontal repair in dogs: effect of rhBMP-2 concentration on regeneration of alveolar bone and perio- 
dontal attachment. J Clin Periodontol 1999; 26: $392-$ 400.

4) Yamaji K, Matsumoto A, Kato H. Aging effect on bone formation induced by recombinant human BMP2 combined with polylactate-polyglycolate-copolymer / gelatine sponge complexes at palatal subperiosteal sites in rats. J Jpn Soc Periodont 1999; 41: 380-391.

5) Matsumoto A, Yamaji K, Kawanami M, Kato H. Effect of aging on bone formation induced by recombinant human bone morphogenetic protein- 2 combined with fibrous collagen membranes at subperiosteal sites. J Periodont Res 2001; 36: 175-182.

6) Yamaji K, Itota T, Izawa S, Nishitani Y, Yoshiyama M. Study on bone formation induced by recombinant human BMP-2 at palatal sites in adult rats. $\mathrm{J}$ Oral Tissue Engin 2006; 4: 37-42.

7) Iwasaka K, Negishi A, Yamaji K, Kawanami M. Influence of streptozotocin-induced diabetes on new bone formation induced by rhBMP-2. J Jpn Soc Periodont 2004; 46: 266-277.

8) Lee JY, Peng H, Usas A, Musgrave D, Cummins J, Pelinkovic D, Jankowski R, Ziran B, Robbins P, Huard J. Enhancement of bone healing based on ex vivo gene therapy using human muscle-derived cells expressing bone morphogenetic protein 2. Hum Gene Ther 2002; 13: 1201-1211.

9) Rachmiel A, Aizenbud D, Peled M. Enhancement of bone formation by bone morphogenetic protein-2 during alveolar distraction: an experimental study in sheep. J Periodontol 2004; 75: 1524-1531.

10) Sugiyama O, An DS, Kung SP, Feeley BT, Gamradt S, Liu NQ, Chen IS, Lieberman JR. Lentivirusmediated gene transfer induces long-term transgene expression of BMP-2 in vitro and new bone formation in vivo. Mol Ther 2005; 11: 390-398.

11) Granjeiro JM, Oliveira RC, Bustos-Valenzuela JC, Sogayar MC, Taga R. Bone morphogenetic proteins: from structure to clinical use. Braz J Med Biol Res 2005; 38: 1463-1473.

12) Park YJ, Kim KH, Lee JY, Ku Y, Lee SJ, Min BM, Chung CP. Immobilization of bone morphogenetic protein-2 on a nanofibrous chitosan membrane for enhanced guided bone regeneration. Biotechnol Appl Biochem 2006; 43: 17-24.

13) Cheung LK, Zheng LW. Effect of recombinant human bone morphogenetic protein-2 on mandibular distraction at different rates in an experimental model. J Craniofac Surg 2006; 17: 100-110.

14) Nishida S, Endo N, Yamagiwa H, Tanizawa T,
Takahashi H. Number of osteoprogenitor cells in human bone marrow markedly decreases after skeletal maturation. J Bone Miner Metab 1999; 17: 171177.

15) Kanatani M, Sugimoto T, Kaji H, Kobayashi T, Nishiyama K, Fukase M, Kumegawa M, Chihara K. Stimulatory effect of bone morphogenetic protein-2 on osteoclast-like cell formation and bone resorbing activity. J Bone Miner Res 1995; 10: 1681-1690.

16) Koide M, Murase Y, Yamato K, Noguchi T, Okahashi $\mathrm{N}$, Nishihara $\mathrm{T}$. Bone morphogenetic protein-2 enhances osteoclast formation mediated by interleukin- $1_{a}$ through upregulation of osteoclast differentiation factor and cyclooxygenase-2. Biochemical and Biophysical Research Communications 1999; 259: 97-102.

17) Kaneko H, Arakawa $T$, Mano H, Kaneda $T$, Ogasawara A, Nakagawa M, Toyama Y, Yabe Y, Kumegawa M, Hakeda Y. Direct stimulation of osteoclastic bone resorption by bone morphogenetic protein (BMP)-2 and expression of BMP receptors in mature osteoclasts. Bone 2000; 27: 479-486.

18) Itoh $\mathrm{K}$, Udagawa $\mathrm{N}$, Katagiri $\mathrm{T}$, Iemura $\mathrm{S}$, Ueno $\mathrm{N}$, Yasuda H, Higashio K, Quinn JMW, Gillespie MT, Martin TJ, Suda T, Takahashi N. Bone morphogenetic protein 2 stimulates osteoclast differentiation and survival supported by receptor activator of nuclear factor-к B ligand. Endocrinology 2001; 142: 3656-3662.

19) Ito Y, Bringas P Jr, Mogharei A, Zhao J, Deng C, Chai Y. Receptor-regulated and inhibitory Smads are critical in regulating transforming growth factor beta-mediated meckel's cartilage development. Dev Dyn 2002; 224: 69-78.

20) Yu Y, Yang JL, Chapman-Sheath PJ, Walsh WR. TGF-beta, BMPS, and their signal transducing mediators, Smads, in rat fracture healing. J Biomed Mater Res 2002; 60: 392-397.

21) Park GT, Morasso MI. Bone morphogenetic protein-2 (BMP-2) transactivates DIx3 through Smad1 and Smad4: alternative mode for DIx3 induction in mouse. Nucleic Acids Res 2002; 30: 515-522.

22) Wildemann B, Kadow-Romacker A, Lubberstedt M, Raschke M, Haas NP, Schmidmaier G. Differences in the fusion and resorption activity of human osteoclasts after stimulation with different growth factors released from a polylactide carrier. Calcif Tissue Int 2005; 76: 50-55. 